will sooner or later be given detailed statements of how much or how little money there is to spend, but this is no substitute for the awareness among the teaching staffs of universities of the ways in which their opcrations are necessarily circumscribed by financial considerations. Internally, the consequences can be quite serious. What sense is there in universities' attempts to operate more efficiently and economically if those who will have to save the pennics are not kept fully informed? And how can academics be expected to form sensible opinions about the long-term strategy for the development of the university to which they belong if the details of now much money there is to spend are regarded as the privileged possession of a handful among them? Outside the universities, however, the consequences of this coyness are even more alarming. In effect, the universities by their pointless gentility are prevented from making the full-blooded claim on public sympathy which their objectives would justify.
What is to be done? The universities themselves could do a lot to help and, if the University Grants Committee is unwilling to make an intelligent comment on quinquennial allocations as these are madc, the Committee of Vice-Chancellors and Principals could well take over that task. But in the long run, the real need is somehow to suppress the feeling among university administrators and even academics that there is some virtue in keeping silence about the ways in which money is spent. So long as universities were private institutions and so long as the numbers of people with whom they dealt were so small that their influence in the economic life of Britain could be neglected, this may have been a tenable position. But the need now is for a much more open conduct of affairs. Since it is public money which is being spent, the universities would be prudent to remember that if they do not voluntarily provide information which is of great public importance, matters may be taken out of their hands.

\title{
Public Transport should be Practicable
}

THIs looks like being a decade in which governments will be preoccupied with issues of public transport, at least in Britain and the United States. After many years of speculation and timid experiment in urban planning, it has now been borne in on a great many people that it is not feasible to plan the shape of cities without at the same time planning the transport networks by which people will move or seek to move from one place to another. In Britain, the issue has been made controversial as well as topical by the energetic way in which Mrs Barbara Castle, Minister of Transport for more than a year, has been reshaping the administrative structure of public transport. The starting point for the policies which will obviously flow freely in the years ahead is the White Paper Public Transport and Traffic (HMSO, 3s. 9d.). Even Mrs Castle's crities have been compelled to admit that this is a formidable and even admirable document. One of its striking and least assailable conclusions is that public transport should be organized on a local basis, not centrally, which will frequently mean the transfer of large parts of existing transport undertakings to local passenger transport authorities, but which will also on some occasions entail that bus companies at present operated by comparatively small local authorities will be swallowed up by larger units. One important innovation is that passenger transport authorities will be required to assume some responsibility for the pattern of railway services, particularly where these are widcly used by commuters, and no doubt the time will come when these passenger transport authorities find themselves paying subventions to the central railway authority for the cost of maintaining publio services which would otherwise be uneconomic. It is, of course, entirely sensible that the costs of subsidies like this should be felt directly at the local level at which they arise, and that machinery should exist for making comparisons between the social bencfits that can be obtained by investing a sum of money in alternative means of transport. The doubts which Mrs Castle's scheme arouses are not doubts of principle but of practice. What prospect is there that the passenger transport authorities established at a local level will be able to seize the opportunities which transport technology now promises? How well will they be able to integrate their policies for the development of public transport with policies for the shape of urban planning under the control of other authorities? How far will they be able to rise above the parochial considerations which bedevil local government in Britain ?

The trouble is that there are now a great many conflicting claims on the attention of those who would more effectively exploit the technology of modern transport. The Ministry of Transport itself has recently been acquiring a commanding expertise in the economics of transport systems, and there is obviously a great deal to be done in the improvement of the efficiency of transport by persuading the users of the transport system to make demands on it which can more easily be satisfied. The danger here, however, is that too great a concern for pricing systems may lead to policies which are aimed at "pricing the motor car off the roads" when the real objective should be to make the most efficient use of the transport system as a whole--trains, buses and private cars included. The force of this argument was well put recently by the Standing Joint Committee on the Buchanan Report which is being sponsored by the engineering institutions.

\section{United States Science Examined}

As this issue of Nature went to press, the OECD was beginning its confrontation with the United States authorities on the report about the condition of science in the United States which has been prepared by the team of examiners which has been at work on the 
problem for the best part of two years. The study is the eighth to have been carried out in the series of studies of national science policies in the 21 member nations of the OECD, but the chances are great that the special circumstances of the United States will bring up questions which earlier reports in the series have not raised. Prominent among these are likely to be questions related to what is sometimes called the technology gap-a cause known to be close to the heart of the OECD. Not merely is there likely to be a serious attempt to draw from American experience in the management of science and technology, but there is also likely to be some attempt to determine the wisdom of trying to follow in Europe some of the developments which have been prominent in the United States in recent years.

The OECD report, which is the basis for the discussions being held in Paris, has been prepared partly by the secretariat of the OECD and partly by a panel which consists of Dr H. G. B. Casimir, director of the Philips Research Laboratories at Eindhoven; $\mathbf{M r}$ Theo Lefevre, a former prime minister of Belgium; M. Pierre Masse, chairman of Electricité de France; and Professor C. H. Waddington of the University of Edinburgh. A full summary of the review of United States Science Policy, together with an account of the confrontation in Paris, will appear in Nature next week.

\section{Drugs' Dark Days}

THe United States pharmaceutical industry must be suffering from a bad case of nostalgia. The good old days of the nineteen-fifties - when wonder drugs brought wondrous profits and gratitude from the public as well-are probably gone for ever. Instead, the federa] government is getting more and more inquisitive about the whole business of medicines: how much they cost to make, whether they perform as advertised, whether those with melodious trade names are better healers than those with clumsy generic names. Two Senate investigations are now in progress, one looking into possible abuses in the diet pill industry, another into the pricing policies of drug manufacturers. The total government spending on drugs by federal, state and municipal authorities continues to increase-it is now $\$ 200$ million a year-so that the authorities are now unlikely to relax their vigilance.

The aura of suspicion created by Senate investigators was even blamed by an executive of one of the pharmaceutical firms found guilty last week for conspiring to control the production and sales of tetracycline. Certainly the jury had a lot to contend with-patent law, chemical formulae, patent and anti-trust laws were all freely quoted during the trial. Their finding that three companies-Charles Pfizer and Company, American Cyanamid Company and the Bristol Myers Company-are guilty of criminal conspiracy in monopolizing the manufacture of tetracycline until 1961 has shaken the industry. The decision, if it is not reversed, opens the door to lawsuits from major purchasers of tetracycline from the defendants. The City of New York and the State of Florida have already filed their suits in the hope of recovering the treble damages allowed by the Sherman Anti-Trust Act against companies convicted of monopoly. The sums eventually paid back to irate customers could exceed those awarded a few years ago when some American electrical companies were convicted of price-fixing.

The industry, not surprisingly, feels hard done by The big laboratories, as the argument goes, bear the costs of all the research and, as soon as they come up with something useful, smaller companies rush in, copy the medicine and sell it at cut-prices. Are the better-known branded products more efficacious? The big companies say they are, and many doctors, including some from the American Defense Department, which has been buying low-priced tetracycline from Italy rather than the expensive domestic brands, agree. The Food and Drug Administration set up a special committee to study the problem of efficacy and equivalence; and the job is harder than anyone had thought. After eighteen months, the committee has asked for more time.

The debate has really just begun. Last year in Congress Senator Long of Louisiana tried to make it mandatory for all public agencies in the medicinebuying business to buy drugs by their chemical rather than by their trade names. He failed, but a vestige of his wish survived in the form of a directive to the Department of Health, Education and Welfare to ask all state governments to promise that the medicines that they were buying for people on relief rolls was purchased at the lowest possible cost. At the very least, this means that more attention will be paid to the question of getting best buys. The price differences between what are said to be equal quantities of the same compound are staggering. The Senate is hearing that public agencies were charged \$2.09 in one case and $\$ 160$ in another for the same quantity of reserpine tablets, and the Justice Department's complaint in the tetracycline case was that antibiotic tablets costing $\$ 2$ or $\$ 3$ a hundred to produce were being sold to the customer at $\$ 51$ a hundred.

Meanwhile, the FDA is getting ready to make public the results of its inquiry into the efficacy of medicines sold in America between 1938 and 1962, when stricter standards were established. The advance reports say that about 10 per cent of the old favourites in the medicine cabinet could be denounced as worthless and some may have to be withdrawn from sale.

\section{Computers More Expensive}

InTERnationaL Business Machines last week announced increases in the cost of both buying and renting its computers in Britain. Renting an IBM machine will cost 10 per cent more, while buying one will cost up to 10 per cent more. The hiring of time at computer bureaux and data centres will go up by between 3 and 10 per cent, and maintenance charges will increase by 4 per cent. These increases, a response to the devaluation of sterling, may well be duplicated by other computer companies which use a large proportion of imported parts - a group which includes every computer manufacturer in Britain, with the possible exception of International Computers and Tabulators.

IBM has also taken the opportunity of announcing a new computer, as part of the 360 series. The new model, the $360 / 25$, falls between the smallest machine in the IBM range, the $360 / 20$, and the next up, the $360 / 30$. It will offer users of the $360 / 20$ a chance to increase their computing power without having to 